\title{
COMPARISON OF FISH COMMUNITY STRUCTURE ON ARTIFICIAL REEFS DEPLOYED AT DIFFERENT DEPTHS ON TURKISH AEGEAN SEA COAST**
}

\author{
Benal Gül $1^{1 * *}$, Altan Lökl ${ }^{1}$, Aytaç Özgül ${ }^{1}$, Ali Ulaş ${ }^{2}, F$. Ozan Düzbastilar ${ }^{2}$ and Cengiz Metrin ${ }^{2}$ \\ ${ }^{1}$ Ege University, Faculty of Fisheries \\ (Bornova, 35100, İzmir, Turkey) \\ ${ }^{2}$ Ege University Underwater Research and Application Center \\ (İskele Urla 35440 İzmir Turkey) \\ **Corresponding author: benalgul@yahoo.com
}

\begin{abstract}
A B S TR ACT
Deployment depth of artificial reefs is one of the most important issue in planning stage and future success. Most of the studies aimed at determination of fish community around artificial reefs were conducted mainly 10-25m depths in Mediterranean and Aegean Sea. The goals of this study are determine and compare of fish community structure around artificial reefs which deployed 20, 30 and $40 \mathrm{~m}$ depths. Underwater visual census technique was used to determine fish species, number of individual and size estimation. There was no statistical difference ( $p>0.05)$ in mean fish biomass and number of individual between the depths. But mean species number was significantly greater on 20 $\mathrm{m}$ in comparison to $30 \mathrm{~m}$ and $40 \mathrm{~m}$ depths $(\mathrm{p}<0.05)$. Furthermore, calculated values of Jaccard and Bray-Curtis indexes showed low similarity (min. 3\% - max. \%37) between depths.
\end{abstract}

\section{R ESUMO}

A profundidade da implantação de recifes artificiais é uma das questões mais importantes no planejamento de etapas e do futuro êxito. A maior parte dos estudos visando determinar a comunidade de peixes em volta de recifes artificiais foi realizada, principalmente, a profundidades de 10-25m no Mediterrâneo e Mar Egeu. Os objetivos deste estudo são determinar e comparar a estrutura da comunidade de peixes em volta de recifes artificiais que foram implantados a profundidades de 20, 30 e $40 \mathrm{~m}$. A técnica de censo visual foi usada para determinar as espécies e obter uma estimativa do número e tamanho dos peixes. Não houve nenhuma diferença estatística (p> 0.05) entre as profundidades, na média da biomassa de peixes e no número de indivíduos. Entretanto, a média do número de espécies foi significativamente maior nos $20 \mathrm{~m}$ em comparação com as profundidades de $30 \mathrm{~m}$ e de $40 \mathrm{~m}(\mathrm{p}<0.05)$. Além disso, os valores calculados dos índices de Zurro-Curtis e Jaccard revelaram pequena semelhança (minuto 3\% - máximo \%37) entre as profundidades.

Descriptors: Artificial reef, Fish community, Underwater visual census, Aegean Sea. Descritores: Recife artificial, Comunidade de peixes, Censo visual, Mar Egeu.

\section{INTRODUCTION}

Artificial reef research in Turkey was begun in 1991 and mainly took place on the Aegean Sea coast (LÖK et al., 2002). Coastal municipalities and fishery cooperatives showed intense interest in artificial reef projects as from 1995. Twenty-two artificial reef projects were planned by coastal municipalities between 1995 and 2009, but artificial reef studies were undertaken only very slowly thereafter. (*) Paper presented at the $9^{\text {th }}$ CARAH - International Conference on
Artificial Reefs and Related Aquatic Habitats on 8-13 November, Curitiba, PR, Brazil.
A better understanding of artificial reef functions and their relationship with environmental factors will make more effective use of these structures possible and facilitate their proper use in fishery management. One of the environmental conditions which is recognized as important to artificial reefs is their depth. The distributions of many species are depth-related. Major changes in fish assemblages on reefs have been noted at depths of around $30 \mathrm{~m}$ off Taiwan and $45 \mathrm{~m}$ off Florida. Depth alters light conditions and thus influences algal composition, abundance and productivity. Depth can also affect water temperature; usually, warm water rises above cold water thus creating a thermocline and this layering can constitute a barrier to some organisms (BOHNSACK et al., 1991). 
Most of the studies aiming at the determination of fish communities in the proximity of artificial reefs have mainly been conducted, in the Mediterranean and Aegean Seas, at depths of 10-25m. For this reason, there are no descriptive or comparative studies on fish community structures around artificial reefs deployed at different depths in the eastern Mediterranean.

Artisanal fishery communities are demanding that artificial reefs should be deployed (or, are calling for the deployment of artificial reefs) in deeper waters. The fishermen involved are supposing that they will thus obtain new fishing grounds where they will be able to catch high value fish such as groupers, red sea bream etc. The Ministry of Agriculture and Rural Affairs has asked the researchers to investigate (or, has asked researchers about) fish community structure on deeper artificial reefs.

The aim of this present study is to determine and compare the fish community structures around artificial reefs deployed at three different depths (20 m, $30 \mathrm{~m}$ and $40 \mathrm{~m}$ ) on the Turkish Aegean Sea coast.

\section{Methods \\ Study Area}

Gümüldür is a coastal village located on the Gulf of Kuşadası, $60 \mathrm{~km}$ south of İzmir (Fig. 1). The sea bottom between 0 and $5 \mathrm{~m}$ is sandy; that between 5 and $15 \mathrm{~m}$ is covered by Posidonia oceanica meadows and is followed by a muddy zone extending to deeper areas. The Gulf of Kuşadası is oligotrophic and its chla values vary between 0.3 and $1.7 \mu \mathrm{g} / \mathrm{l}$. During the study period, the lowest sea surface temperature (140C) was recorded in February and the highest (250C) in August.

\section{Artificial reef Design and Deployment Plan}

Concrete culverts of $30-\mathrm{cm}$ diameter and $105 \mathrm{~cm}$ in length were used as artificial reef units (Fig.2). To construct a reef set, six of these units were stacked (3-2-1) into a pyramid. Nine pyramid-shaped reef sets were constructed and three of them were deployed at each depth $(20,30$ and $40 \mathrm{~m})$ in April 2006 (Fig. 2). The distance between the sets was of approximately $25 \mathrm{~m}$.

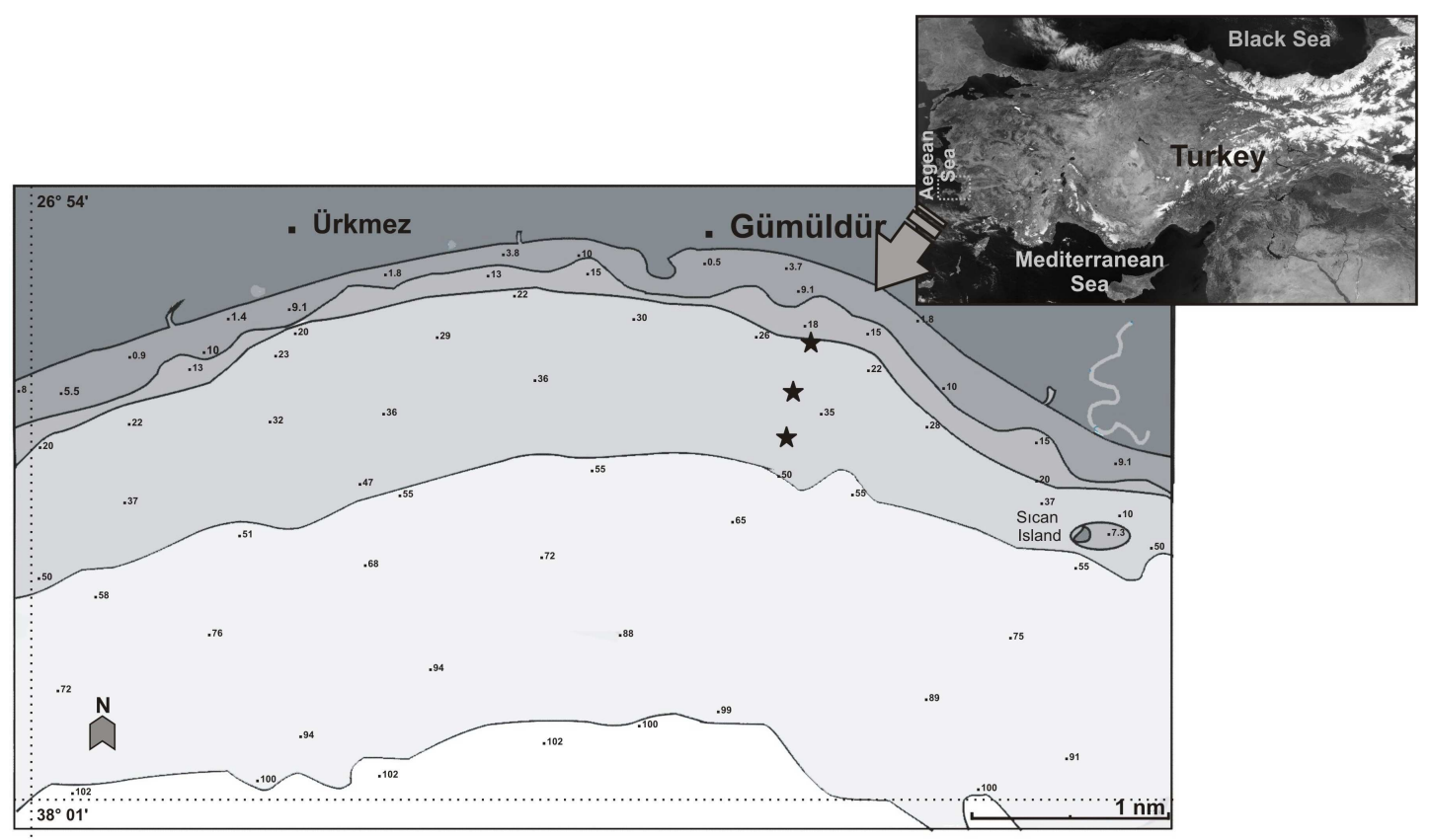

Fig. 1. Study area and location of artificial reefs. 

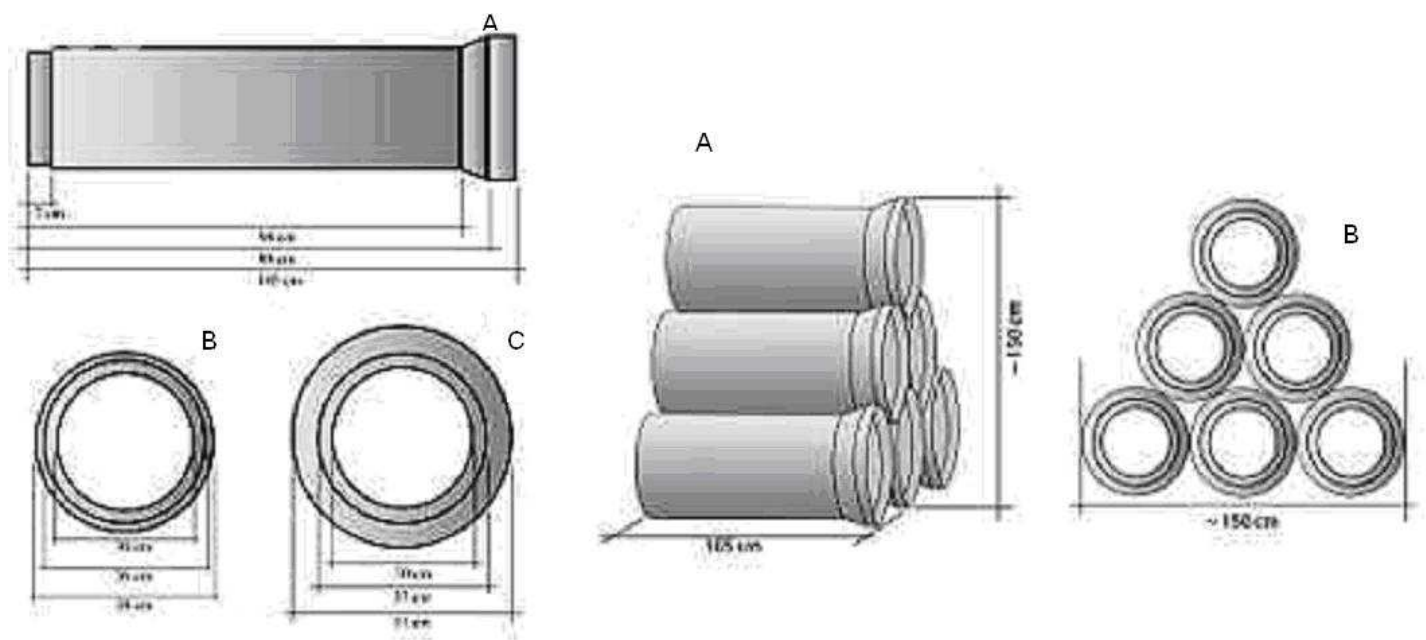

Fig. 2. Artificial reef design and illustration of reef deployment.

Sampling

Fish communities were sampled for species composition, abundance and fish size between July 2006 and June 2008. The same divers undertook censuses of all fish at the same time of day, identified the species and estimated individual sizes using visual census methods (HARMELIN-VIVIEN et al., 1985; BORTONE; KIMMEL, 1991; BOHNSACK et al., 1994). Large fish were first surveyed and then the reefs were closely examined for small and cryptic species. The three artificial reef sets at each depth were visited during all the observations.

\section{Data Analysis}

Fish species richness, abundance, biomass and biodiversity $\left(\mathrm{H}^{\prime}\right)$ were examined using a mixed model analysis of variance (ANOVA) using SPSS 15.0 software. A probability value of less than 0.05 by ANOVA was accepted as a significant difference. Bray-Curtis dissimilarity and Jaccard similarity indices were used to examine potential differences in fish community structure between depths.

\section{REsUlts}

A total of 30 species belonging to 14 families were recorded on all the reef sets. The most abundant families were Sparidae and Serranidae (Table 1). The dominant Sparid species was Pagellus acarne, which represented $48 \%$ of the total bream abundance. Eighteen species were classified as of commercial value and carnivores were clearly dominant.
There were significantly higher family number and species richness on artificial reefs at $20 \mathrm{~m}$. Eleven families and 20 species were recorded during the study period. C.chromis was the dominant species and represented $50 \%$ of total fish abundance. Seventeen species belonging to 10 families were observed at $30 \mathrm{~m}$. and 6 families were represented by 13 species at $40 \mathrm{~m}$. Pagellus acarne was the dominant species at $30 \mathrm{~m}$ and $40 \mathrm{~m}$. and represented $\sim 60 \%$ of total abundance on both artificial reef sets.

Although the artificial reefs at $20 \mathrm{~m}$ depth have the highest species number, mean abundance and mean biomass were greater on the artificial reefs at 40 $m$ than on those at the other depths. Shannon-Wiener values varied between 0.75 and 1.7 on the artificial reef at $20 \mathrm{~m}$ and biodiversity increased continuously after deployment. While $30 \mathrm{~m}$ biodiversity values varied between 0.19 and 1.17 , the lowest values were found on the artificial reefs at $40 \mathrm{~m}$ (between 0.04 0.69 ).

Species richness values were statistically significantly different between depths $(p<0.05)$. Statistical analysis shows that no statistically significant differences occurred when comparing fish abundance and biomass at the various artificial reef depths ( $p>0.05)$.

Seasonal changes of mean species number, abundance, biomass and biodiversity show similar curves for all the artificial reef depths (Fig. 3).

The Jaccard index between depths was found to be $37 \%$ between $20 \mathrm{~m}$ and $30 \mathrm{~m}, 36 \%$ between 20 $\mathrm{m}$ and $40 \mathrm{~m}$ and $27 \%$ between $30 \mathrm{~m}$ and $40 \mathrm{~m}$. The Bray Curtis index showed great dissimilarity $(15 \%$ between $20 \mathrm{~m}$ and $30 \mathrm{~m}, 3 \%$ between $20 \mathrm{~m}$ and $40 \mathrm{~m}$ and $28 \%$ between $30 \mathrm{~m}$ and $40 \mathrm{~m}$ ) (Fig. 4). 
Table 1. Species list of artificial reef site.

\begin{tabular}{|c|c|c|c|c|}
\hline \multirow{2}{*}{ Family and Species } & \multirow{2}{*}{ Diet } & \multicolumn{3}{|c|}{ Residence } \\
\hline & & $20 \mathrm{~m}$. & $30 \mathrm{~m}$. & $40 \mathrm{~m}$. \\
\hline \multicolumn{5}{|l|}{ Muraenidae } \\
\hline Muraena helena & Carnivor & & Transient & \\
\hline \multicolumn{5}{|l|}{ Congridae } \\
\hline Conger conger & Carnivor & Transient & & Transient \\
\hline \multicolumn{5}{|l|}{ Gadidae } \\
\hline Phycis phycis & Carnivor & & Transient & \\
\hline \multicolumn{5}{|l|}{ Serranidae } \\
\hline Serranus hepatus & Carnivor & Transient & Transient & \\
\hline Serranus cabrilla & Carnivor & Resident & Resident & Resident \\
\hline Serranus scriba & Carnivor & & & Transient \\
\hline Epinephelus costae* & Carnivor & Visitor & & Transient \\
\hline E. caninus & Carnivor & Transient & & \\
\hline E. aeneus & Carnivor & Transient & Transient & \\
\hline \multicolumn{5}{|l|}{ Apogonidae } \\
\hline Apogon imberbis & Carnivor & Transient & & Transient \\
\hline \multicolumn{5}{|l|}{ Carangidae } \\
\hline Seriola dumerili* & Carnivor & & & Transient \\
\hline Trachurus mediterraneus & Carnivor & & & Transient \\
\hline \multicolumn{5}{|l|}{ Mullidae } \\
\hline Mullus barbatus* & Carnivor & & Transient & \\
\hline Mullus surmelatus* & Carnivor & Transient & & \\
\hline \multicolumn{5}{|l|}{ Sparidae } \\
\hline Sparus aurata* & Carnivor & Transient & & \\
\hline Dentex dentex* & Carnivor & & Transient & \\
\hline Diplodus annularis* & Carnivor & Transient & Transient & Transient \\
\hline Diplodus vulgaris* & Carnivor & Transient & Transient & Transient \\
\hline Oblada melanura* & Carnivor & Transient & & \\
\hline Pagellus erythrinus & Carnivor & & Transient & Transient \\
\hline Pagellus acarne* & Carnivor & & Transient & Visitor \\
\hline Boops boops* & Omnivor & & Transient & Transient \\
\hline \multicolumn{5}{|l|}{ Pomacentridae } \\
\hline Chromis chromis & Carnivor & Resident & Transient & \\
\hline \multicolumn{5}{|l|}{ Labridae } \\
\hline Symphodus mediterraneus & Carnivor & Transient & & \\
\hline Symphodus doderleini & Carnivor & Transient & & \\
\hline \multicolumn{5}{|l|}{ Gobiidae } \\
\hline Gobius niger & Carnivor & Transient & Transient & \\
\hline \multicolumn{5}{|l|}{ Blennidae } \\
\hline Parablennius rouxi & Herbivor & Visitor & Resident & Transient \\
\hline \multicolumn{5}{|l|}{ Scorpaenidae } \\
\hline Scorpaena porcus & Carnivor & Transient & & \\
\hline Scorpaena scrofa* & Carnivor & Visitor & Transient & \\
\hline \multicolumn{5}{|l|}{ Balistidae } \\
\hline Balistes capriscus & Carnivor & Transient & Transient & \\
\hline
\end{tabular}



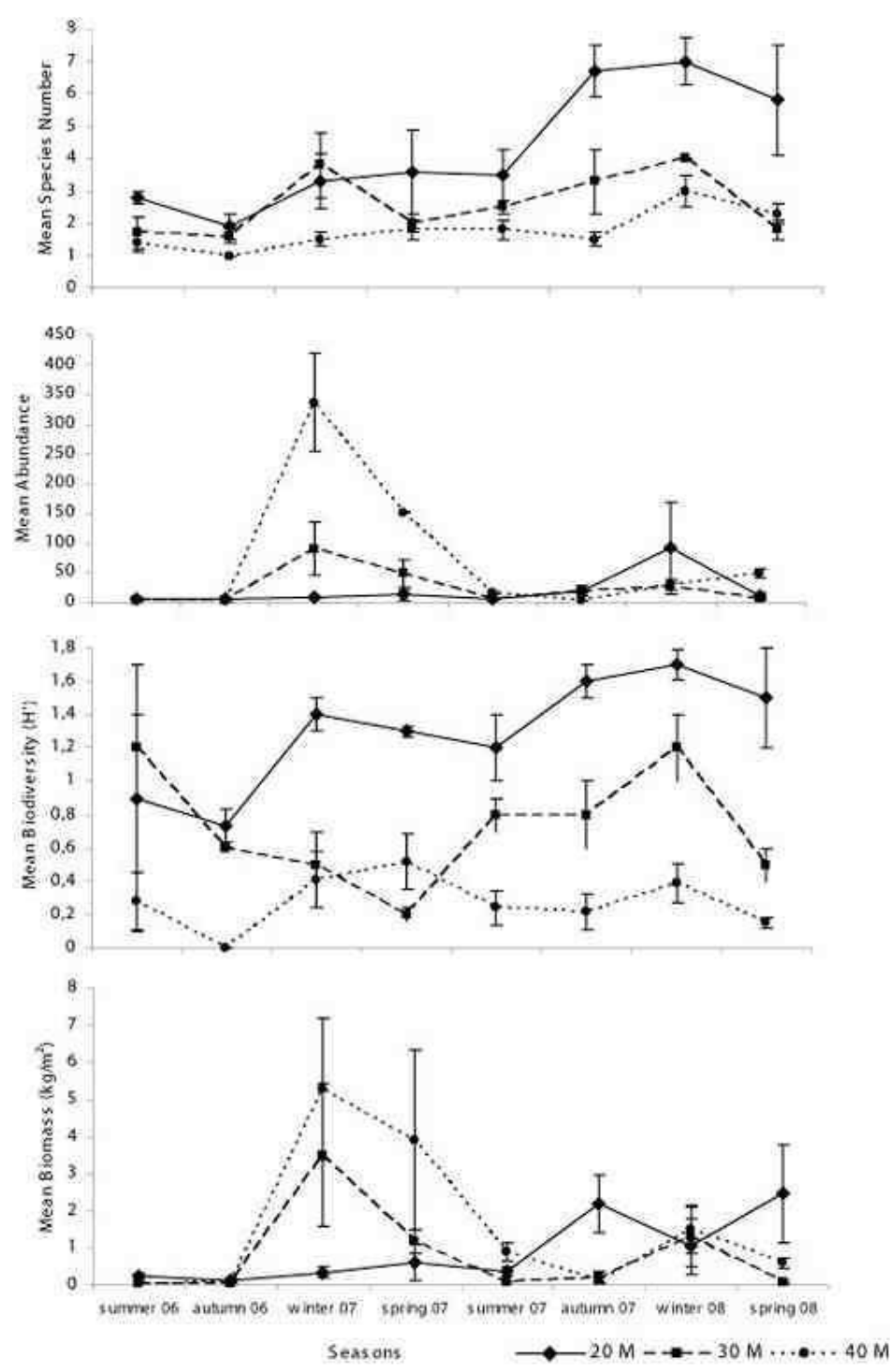

Fig. 3. Changes of Mean and Standard deviations of fish community parameters.

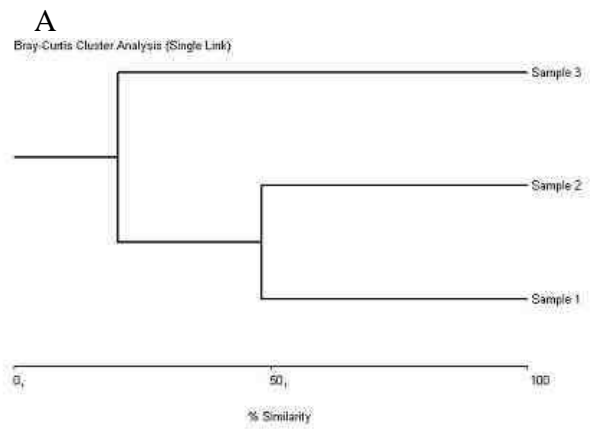

\section{B}

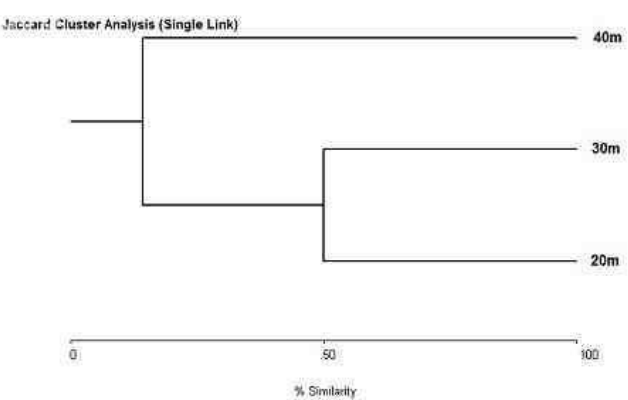

Fig. 4. Similarities between artificial reefs at different depths (a. Dendrogram of Bray Curtis Cluster Analysis, b. Dendrogram of Jaccard Cluster Analysis). 


\section{DisCUSSION}

Results show that there is a major difference in fish composition as between depths, especially between that at $20 \mathrm{~m}$ and $40 \mathrm{~m}$. Artificial reefs at $20 \mathrm{~m}$ depth had high species number, though each species was represented by few individuals. Artificial reefs at $40 \mathrm{~m}$, although having the lowest species number, present schools of some species which contribute to higher abundance and biomass. The higher commercial value of these schools permits us to affirm that deeper artificial reefs can be use as tools to support recreational small-scale fisheries. But longterm observations and fisheries studies would be necessary to permit one to make this kind of suggestion.

There is no possibility of comparing this study with others on the effect of depth on the fish composition of artificial reefs. Relini et al. (2007) reported that six barges, two each at 20,30 and $40 \mathrm{~m}$ depth, had been immersed in the coastal waters off Camogli in October 1979, but that they had not been studied since.

Gül et al. (2006) conducted a study at the different artificial reef sites in the same region and found that 6 years after the reefs' deployment, the fish assemblages on them, in a muddy area, presented 12 families and 32 species. A comparison of the results showed that, especially on the artificial reefs at $20 \mathrm{~m}$, succession proceeds rapidly.

The absence of many species and the presence of some schools on artificial reefs at $40 \mathrm{~m}$ depth may be due to the surrounding substrate. In Gümüldür, the seagrass meadows begin near the seashore and descend to $\sim 15 \mathrm{~m}$ depth. Some species (e.g. labrids) were observed traveling between muddy sea-bed and seagrass meadows on the artificial reefs at $20 \mathrm{~m}$ depth. However, at the artificial reefs at $40 \mathrm{~m}, \sim 1$ mile from the shore, there is no connection with the seagrass meadows. On the $30 \mathrm{~m}$ and $40 \mathrm{~m}$ deep reefs the dominance of Pagellus acarne, which prefers worms, mollusks and crustaceans, may be due to the surrounding muddy area. The absence of some species may thus be due to habitat relations (or, their relationships with specific habitats.). The consideration of this kind of result will be of importance to the success of artificial reef projects.

Progress in fish compositions could be clearly observed at all depths over the 2-year period. Low species numbers, abundance, biomass and biodiversity values increased over time. This process took place more quickly at $20 \mathrm{~m}$ depth, especially as regards species number. The effect of sun light may be an important factor contributing to this result. The reefs at $30 \mathrm{~m}$ always showed intermediate values between those at $20 \mathrm{~m}$ and $40 \mathrm{~m}$ depths.
A large number of carnivore species was recorded and their dominance may be the cause of their having such a marked effect on the presence/absence of larvae. Bohnsack et al. (1991) suggest that carnivore species tend to be dominant in fish assemblages.

The consideration of this kind of result will be of importance to the success of artificial reef projects, especially as regards their use as a tool for fisheries management.

\section{AcKNOWLEDGMENTS}

We wish to thank B. Rüzgar and E. Ergün for their logistical support as also the crew members of the Research Vessel (EGESÜF), O. Öner and A. Aksade. We also thank G. Metin, İ. Aydın, N. Güneş and $\mathrm{M}$. Bilecenoğlu for their help during the cruise and assistance with the data analysis.

\section{REFERENCES}

BOHNSACK, J. A.; JOHNSON, D. L.; AMBROSE, R. F. Ecology of artificial reef habitats and fishes. In: SEAMAN, JR, W.; SPRAGUE, L. M. (Ed.). Artificial habitat for marine and freshwater fisheries. San Diego: Academic Press, 1991. p. 61-107.

BOHNSACK, J. A.; HARPER, D. E.; MCCLELLAN, D. B.; HULSBECK, M. Effects of reef size on colonization and assemblage structure of fishes at artificial reefs off southeastern Florida, U.S.A. Bull. mar. Sci., v. 55, n. 23, p. 796-823, 1994.

BORTONE, S. A.; KIMMEL, J. J. Environmental assessment and monitoring of artificial reefs. In: W. SEAMAN JR., W. ; SPRAGUE, L. M. (Ed.). Artificial habitats for marine and freshwater fisheries. San Diego: Academic Press, 1991. p. 177-236.

GÜL, B.; LÖK, A.; ULAŞ, A.; DÜZBASTILAR, F. O. Effects of surrounding substrates on artificial reef fish assemblages off the Aegean Sea coast of Turkey. Bull. mar. Sci.., v. 78, n. 1, p. 221-226, 2006.

HARMELIN-VIVIEN, M.; HARMELIN, J. G.; CHAUVET, C.; DUVAL, C.; GALZIN, R.; LEJEUNE, P.; BARNABÉ, G.; BLANC, F.; CHEVALIER, R.; DUCLERC, J.; LASSERRE, G. Evaluation visuelle des peuplements et populations de poissons. Méthodes et problèmes. Rev. Ecol. (Terre Vie), v. 40, p. 467-539, 1985.

LÖK, A.; METIN, C.; ULAŞ, A.; DÜZBASTILAR, F.O.; TOKAÇ, A. Artificial reefs in Turkey. ICES J. mar. Sci., v. 59, p. 192-195, 2002.

RELINII, G.; RELINII, M.; PALANDRI, G.; MERELLO, S.; BECCORNIA, E. History, ecology and trends for artificial reefs of the Ligurian Sea, Italy. Hidrobiologia, v. 580, p. $193-217,2007$

(Manuscript received 11 March 2010; revised 28 May 2011; accepted 15 March 2011) 